\title{
Alternative protein sources in the nutrition of farm animals
}

\author{
By
}

IBRAHIM A. ELSAYED

Arish University, faculty of Environmental Agricultural Sciences, Animal Production Research Institute (APRI), Department of Animal Nutrition Research , i_elsayed@Aru.edu.eg, Cairo,Egypt

\begin{abstract}
:
Protein requirement and its demand of farm animals became one of the critical problems in nutrition on a global scale. Protein requirement has been an explicit demand for a long period with soybean meal and animal protein, but recently there are some limitations in relation to their use and the availability of the high quality fishmeal decreases constantly. For this reason there is increased demand for finding new protein sources which could be the alternatives of soybean meal and fishmeal. Alternative protein sources can be divided into seven categories, according to their origin. In different countries, their use depends on the availability in large quantity and at reasonable price. There is a long tradition of using legume seeds, as alternatives of soybean. Most of them contain some anti-nutritive compounds, but it can be reduced with systematic selection. Oilseed meals are also generally use in poultry and pig nutrition, but those crude protein content varied, depending on the oil extraction technology. Green fodder and leaf protein was also proposed as alternative protein sources, but their use is limited, in particular because of the market price. The amount of bioethanol and starch industry by-products increases gradually in recent years, therefore those became alternatives of soybean meal, or in much less extend, fishmeal. However, amino acid composition of such by-products are far from optimal for poultry and pig; therefore, in the case of their use amino acid supplementation is necessary. Several novel protein sources are proposed in the last decade, such as algae or insect proteins. Recently, their availability and use is limited, but in the near future those would be alternative protein sources in monogastric animal nutrition.
\end{abstract}

Keywords: alternative protein sources, oilseeds, legumes, alfalfa, algae, insect protein, DDGS, CGF 


\section{Introduction}

Nowadays there are lot of challenges in nutrition of farm animals, for instance ban of nutritive antibiotics, solicitousness against genetically modified organisms, unpredicted changes of market price etc. Among those challenges the lack of protein, the second most expensive nutrient following energy, is one of the most critical problem all around the world, due to the dramatic increase of farm animal population, in particular in some developing countries (McLeod, 2011). Demand of the continuously increasing protein requirement may arise some problems, because most of soybean meal, the traditional protein source, mostly produced from genetically modified varieties (Karuga, 2017). The other main protein source, fishmeal also critical, because its total production decline, due to overfishing of the oceans (FAO, 2014). However, there different, but not widely used, other protein sources available, which are can be alternatives of soybean meal and fishmeal (Table 1).

Table 1. Alternative protein sources for the replacement of soybean meal and fishmeal in the nutrition of farm animals

Category

Oilseeds

Legume seeds

Legume green fodders

Leaf proteins

Aquatic protein sources

Insects and larvae

Industrial by-products

\section{Oilseeds}

Rapeseed meal or Canola meal are well known and widely used protein source in animal nutrition as replacement of soybean meal. Crude protein content of the meal is $30-40 \%$, depends on the method of oil extraction.

The main limiting factor for using rapeseed meal is its antinutritive compound content, in particular glucosinolates, which have undesirable effect in poultry and pig. However, glucosinolate content can be decrease with plant breeding, and recently there are varieties with low glucosinolate content available. The maximum concentration of glucosinolates in the feed components of monogastric animals should be less than $12000 \mathrm{mg} \mathrm{kg}^{-1}$ of whole seed and less than 20160 $\mathrm{mg} \mathrm{kg}^{-1}$ of extracted meal (Tripathi és Mishra, 2007). Avoiding that problem the use of rapeseed protein concentrate was proposed, because it is free of glucosinolates, and protein content is higher, about 57\% (Jones, 1979).

Sunflower meal is also a well-known alternative protein source, but it has relatively high phenolics, in particular chlorogenic acid, content, which impairs the availability of protein (Gonzalez-Perez et al., 2002), and this is the main limiting factor of its use (Mulder, 2010). Amino acid composition of sunflower 
meal protein is not optimal for monogastric animals, therefore amino acid supplementation requires if used.

Extracted cottonseed meal is also a potential alternative of soybean meal of fishmeal, but the main problem with its use that in most countries only genetically modified varieties are available (Brookes and Barfoot, 2016). Protein content depends on the variety and the mode of oil extraction, but relatively high, $30-50 \%$. However the digestibility of its

protein is moderate (70\%). Amino acid composition of cottonseed meal also not optimal for monogastric animals, because of its low lysine content. Cottonseed also contains an anti-nutritive compound, gossypol, which cannot inactivate by traditional feed manufacturing technologies.

Gossypol has metal chelating property, therefore iron supplementation requires when use (Światkiewicz et al., 2016).

Palm kernel meal is made from the seed of oil palm (Elaeis guinensis) after oil extraction. Its nutrient content is low, for instance crude protein content is about 9.50\%, and its amino acid composition is far from optimal (lysine: 0.36\%; methionine: $0.20 \%$ ). However, it is available in high quantity in some lowincome countries (Index Mundi, 2018).

\section{Legume seeds}

Sweet lupine has long tradition as protein source because of its high protein content (32-42\%), depending on the variety and method of de- hulling (Sujak et al., 2006). Digestibility of protein and amino acid content of sweet lupine is about $85 \%$, which can be improves with hydrothermal treatment and fine grinding (Pieper et al., 2016). Amino acid composition requires methionine supplementation, in particular for poultry (Table 2). Limitation of its use the lupine alkaloid content, which can be decrease with genetic selection, and if it is lower than $0.04 \%$, safe even for young animals (Ciesiolka et al., 2005). High nonstarch polysaccharide (NSP) content of sweet lupine also may arise undesirable effects in poultry, which can be decrease with de-hulling and addition of exogenous NSP enzymes, such as xylanase and cellulase.

\begin{tabular}{lc} 
Table 2. Amino acid composition of sweet lupine protein (Petterson, 2000) \\
\cline { 2 - 2 } Amino acid & Content $(\%)$ \\
\hline Lysine & 1.63 \\
Methionine & 0.24 \\
Cysteine & 0.40 \\
Methionine + Cysteine & 0.64 \\
Threonine & 1.13 \\
Tryptophan & 0.30 \\
Leucine & 2.30 \\
Histidine & 0.73 \\
Serine & 1.56 \\
Phenylalanine & 1.34
\end{tabular}




\begin{tabular}{ll} 
Tyrosine & 1.58 \\
Proline & 1.32 \\
Alanine & 1.09 \\
\hline
\end{tabular}

Source: Petterson (2000)

Field pea is a widely cultivated legume seed in Europe (Mordor Intelligence, 2017), because it has importance either in animal and human

nutrition. Protein content of field pea seed is high (21-25\%), and its amino acid composition is close to soybean, therefore only moderate amino acid supplementation requires when use in the nutrition of monogastric animals. Because of its anti-nutritive compound, trypsin inhibitor, content, heat treatment requires before use (Van Krimpen et al., 2013).

Horse bean is cultivated worldwide because the different cultivars have high adaptability even to extreme conditions (Factfish, 2018). Its use in animal nutrition is limited, because most of them used as human food. Protein content is lower than soybean meal (25-27\%), but its amino acid composition is close to soybean, and digestibility of its protein and amino acids also good. Horse bean, such as other legumes, contains anti- nutritive factors, such as trypsin inhibitors and tannins, which can be partially decomposed by heat treatment. Another possibility is to select low anti-nutritive compound containing varieties. Horse bean contains other potentially toxic compounds, vicine and divicine alkaloid glycosides, which are cause favism either humans or animals. Those can be decompose efficiently by cooking, but this method is not useful in feed technology, because of high energy requirement. However, there are some research about the potential of using antioxidants against the toxic

effects of alkaloid glycosides (Marquardt and Arbid, 1988).

Chick pea (Lathyrus sativus) is not a common protein source, but its crude protein content of 26-27\%, and amino acid composition is similar than field pea, namely requires methionine and cysteine supplementation when use in poultry nutrition. There are some anti-nutritive factor, such as trypsin inhibitor, in chick pea, therefore heat treatment requires before use in monogastric animals. It also contains a neurotoxic compound, $\beta$-N- oxalyl-L- $\alpha, \beta$-diamino-propionic acid, which also can be efficiently decompose by hydrothermal treatment (Baldinger et al., 2016).

Velvet bean (Mucuna pruriens) is also useful alternative of soybean, but it is common only in India. In poultry nutrition the inclusion rate can be increase up to $40 \%$ in complete feed, without changes of the production traits (Vadivel et al., 2011). Average crude protein content is $26.3 \%$, but its use limited by its antinutritive compound content, such as phenolics, tannins, trypsin inhibitor and phytohaemagglutinating activity. Those anti-nutritive factors have low nutritional 
significance if the beans are properly processed, for instance by soaking in sodium- hydrogen carbonate solution (Vadivel and Janardhanan, 2000).

Legume green fodders

Alfalfa is the main fodder in this group, which can be use as protein source in different form and after different methods of drying or other type of processing. Alfalfa produces the highest amount of protein per

hectare. Based on the calculation that its average crude protein content is $19 \%$, and the yield is about 13 tonnes per hectare, it means $2400 \mathrm{~kg}$ protein, which is about three-times more than protein yield of soybean.

Protein yield of alfalfa depends on the percentage of leaves; therefore those cultivars are preferable, which have the highest. Use of alfalfa was limited for a long period in monogastric, mainly pig, nutrition due to its saponin content, but recently saponin-free cultivars are available (Sen et al., 1998).

\section{Leaf proteins}

Leaf proteins are valuable alternative protein sources; in particular alfalfa leaf use for the production of leaf protein concentrates. The main problem is the extraction and purification of leaf protein, because those have marked effect on the physico-chemical properties, therefore nutritive value, of proteins. For instance, digestibility decreased as a consequence of Maillard reaction, formation of lysino-alanine by oxidised polyphenols, or racemisation, which decrease the absorption of lysine and other amino acids (Moughan és Rutherfurd, 2008). The accurate extraction resulted high value protein, even in comparison with soybean meal (Table 3).

Table 3. Nutrient content of alfalfa leaf protein concentrate in comparison with soybean meal

\begin{tabular}{lcc}
\hline Nutrient & Soybean meal & $\begin{array}{c}\text { Alfalfa leaf protein } \\
\text { concentrate }\end{array}$ \\
\hline Crude protein (\%) & 46.0 & 53.5 \\
Crude fat (\%) & 2.0 & 11.3 \\
Crude fibre (\%) & 5.5 & 6.0 \\
Lysine (\%) & 0.3 & 0.3 \\
\hline
\end{tabular}

Source: Bódi and Deme

(2018)

Microalgae

Nowadays among the blue-green algae Aphanizomenon flosaquae, Spirulina maxima and Spirulina pratensis cultivated in large-scale, while among the green algae some Chlorella species used, because of their valuable protein content. The different algae contain 25-50\% crude protein on dry matter basis (Becker, 2007), but they have high water content, therefore drying requires high energy costs. 
Data from large scale trials are not available about their efficacy in farm animals (Christaki et al., 2010), but at experimental level most of them, in particular Spirulina, showed high protein utilization, and some additional positive effects, such as improvement of immune response (Kovács et al., 2016).

\section{Macroalgae}

Pondweed or seaweed mainly cultivated in Asia, but not for protein, but alginate production, also use as human food, and use as organic fertilizer. Those are potential protein sources with different crude protein content (10-30\% on dry matter basis), but no results of animal feeding trials are available.

\section{Duckweed}

Crude protein content is about $35-45 \%$ of dry matter, but it depends on the species and also the nutrient content of the environment. For instance in nutrientrich environment, such as sludge, the crude protein content of Lemna gibba reach $40 \%$, but in low nutrient content environment it is only 9\% (Hasan and Chakbari, 2009). Up to now there is no method for using duckweed as animal feed, because the drying procedure is very expensive, and no effective method available for the extraction of its protein content. The other problem with the use of duckweed is the production environment, which may contain hazardous materials, such as heavy metals.

\section{Insect protein}

Insect protein is a valuable alternative source because of high efficiency of production, and waste materials can be used for feeding insects and larvae. European Union allowed to use insects and their larvae only in the nutrition of fishes and pets and other farm animal species can be feed only with the protein hydrolysates of insect protein with a molecular weight lower than 10000 Daltons (Commission Regulation 2017/893).

Other important criteria for using insects in farm animal nutrition is that their production should be meet the criteria of the Regulation (EC) No 1069/2009. EFSA (2015) qualified the insects, and the following species found as safe either for direct feeding or as protein source, based on detailed toxicological evaluation: black solider fly (Hermetia illucens), house fly (Musca domestica), yellow mealworm (Tenebrio molitor), lesser mealworm (Alphitobius diaperinus), house cricket (Acheta domesticus), banded cricket (Gryllodes sigillatus) and field cricket (Gryllus assimilis).

The most investigated is the larvae of black solider fly, which is a valuable alternative protein source (Table 4). It can be use as replacer of soybean meal in poultry nutrition up to about $25 \%$ (Cullere et al., 2016).

Table 4. Nutrient content of dry and defatted black soldier fly larvae

Nutrient Dry larvae Defatted larvae




\begin{tabular}{lcc}
\hline Crude protein content (\%) & 40.88 & 60.69 \\
Crude fat content (\%) & 20.99 & 7.97 \\
Lysine (\%) & 1.93 & 2.96 \\
Methionine (\%) & 0.49 & 0.72 \\
Cysteine (\%) & 0.31 & 0.47 \\
Threonine (\%) & 1.37 & 2.01 \\
Tryptophan (\%) & 0.45 & 0.71 \\
\hline
\end{tabular}

Source: Cullere et al. (2016)

Housefly larvae has also high crude protein content (63\%), and its amino acid composition also optimal for monogastric animals, because it has 3.8\% lysine and $1.6 \%$ methionine content. For that reason approximately $50 \%$ of soybean meal can be replace with dry or defatted housefly larvae.

Yellow mealworm larvae has excellent utilization capacity of organic wastes, because can produce about $1 \mathrm{~kg}$ protein from about $1.7 \mathrm{~kg}$ of organic waste. Inclusion rate in poultry nutrition is a maximum of $10 \%$, which can be replace about $80 \%$ of soybean meal resulting the same production traits (Ramos-Elorduy et al., 2002).

House cricket contains $62 \%$ crude protein in dried form, but deficient in methionine, tryptophan and arginine (Table 5), which requires amino acid supplementation, in particular when all of the soybean meal replaced with house cricket.

Table 5. Amino acid composition of house cricket protein

\begin{tabular}{lc}
\hline Amino acid & House cricket \\
\hline Lysine & 3.48 \\
Methionine & 0.93 \\
Threonine & 3.05 \\
Tryptophan & 0.38 \\
Tyrosine & 2.52 \\
Histidine & 1.60 \\
Serine & 7.26 \\
Proline & 3.62 \\
Glutamic acid & 3.83 \\
Alanine & 3.74 \\
Leucine & 4.50 \\
Phenylalanine & 1.36 \\
\hline
\end{tabular}

Source: DeFoliart et al.

(1987)

Silkworm (Bombyx mori) pupae is a well-known protein source outside the EU. For instance the annual silkworm larvae production in China is about 150000 tonnes, and the dry pupae contains $46.7 \%$ crude protein

and $32.2 \%$ crude fat (Yaowang, 1989). Silkworm pupae generally use replacing fishmeal in poultry diet even up to $100 \%$ (Khan et al., 2016). 
Grasshoppers are also generally use in animal nutrition in many countries of Africa or Asia. The well-known grasshoppers are the red locusts (Nomadacris septemfaciata) and the brown locust (Locustana pardalina), however other large grasshoppers also known as protein sources because their crude protein content is $50-65 \%$ in dry form, therefore about $20-40 \%$ soybean meal can be replace (Esmail, 2017).

\section{Industrial by-products}

Some industrial by products, such as distillers dried grains with solubles (DDGS) from bioethanol industry and corn gluten feed (CGF) from starch industry, have high protein content, therefore there are potential alternative proteins sources. Amino acid composition of DDGS or CGF protein is not optimal for monogastric animals because the low level of lysine and tryptophan, if they obtained from fermentation/processing from corn seed.

The highest amount of by-product from the bioethanol industry is DDGS (300 kg $\mathrm{t}^{-1}$ of processed corn). Average soybean replacement rate of DDGS is about $0.40-0.45$, based on crude protein content. Nutrient, including crude protein, content of DDGS depends on the cereal grain, but also type of the fermentation technology (Table 6). DDGS can be use in broiler chicken rearing up to $18 \%$ inclusion rate (Heincinger et al., 2011), but in turkey fattening can be increase up to $25 \%$ without decrease of production traits, together with appropriate amino acid supplementation (Heincinger et al., 2012). In pig nutrition the relative value of DDGS to corn is 120-125, while to soybean meal is $45-55$.

Table 6. Nutrient content of DDGS of different origin

\begin{tabular}{lcr}
\hline Nutrient & & Content (\%) \\
\hline Dry matter & $87-93$ & \\
Crude protein & $23-29$ & \\
Crude fat & $3-12$ & \\
Crude fibre & $2.8-4.2$ & \\
Lysine & & $0.59-0.89$ \\
\hline
\end{tabular}

CGF can be use in dried form in the nutrition of poultry and pig. CGF contains mainly the protein and fibre components of corn seed, but low in starch and without germ. Therefore, it has higher protein and fibre content than the seed with low fat and starch content (Table 7). Amino acid composition is not optimal for poultry and pig because low levels of lysine and tryptophan.

Table 7. Nutrient content of dried CGF of different origin

\begin{tabular}{lcc}
\hline Nutrient & & Content (\%) \\
\hline Dry matter & $86-90$ & \\
Crude protein & & $21.5-23.9$ \\
Crude fat & $1.2-1.4$ & \\
Crude fibre & $2.8-4.2$ & \\
Lysine & & $0.59-0.68$ \\
\hline
\end{tabular}




\section{References}

Baldinger, L.-Hagmüller, W.-Minihuber, U.-Schipflinger, M.-Zollitsch, W. (2016): Organic grass pea (Lathyrus sativus L.) seeds as a protein source for weaned piglets: Effects of seed treatment and different inclusion rates on animal performance. Renewable Agricultural and Food Systems. 31: 269279.

Becker, E. W. (2007): Micro-algae as a source of protein. Biotechnology Advances.

25: 207-210.

Bódi L.-Deme A. (2018): Veszteségből fehérjekoncentrátum. Magyar Mezőgazdaság. 73. 12: 28-31.

Brookes, G.-Barfoot, P. (2016): Global income and production impacts of using GM crop technology 1996-2014. GM Crops \& Food. 7: 38-77.

Christaki, E.-Karatzia, M.-Florou-Paneri, P. (2010): The use of algae in animal nutrition. Journal of the Hellenic Veterinary Medical Society. 61: 267-276.

Ciesiolka, D.-Muzquiz, M.-Burbano, C.-Altares, P.-Pedrosa, M. M.-Wysocki, W.- Folkman, W.-Popenda, M.-Gulewicz, K. (2005): An effect of various nitrogen forms used as fertilizer on Lupinus albus L. yield and protein, alkaloid and alpha-galactosides content. Journal of Agronomy and Crop Science. 191: 458- 463.

Commission Regulation (2017): (EU) 2017/893 of 24 May 2017 amending Annexes I and IV to Regulation (EC) No 999/2001 of the European Parliament and of the Council and Annexes X, XIV and XV to Commission Regulation (EU) No 142/2011 as regards the provisions on processed animal proteins. Official Journal of the European Union. L 138/92.

Cullere, M.-Tasoniero, G.-Giaccone, V.-Miotti-Scapin, R.-Claeys, E.-De Smet, S.-Dalle Zotte, A. (2016): Black soldier fly as dietary protein source for broiler quails: apparent digestibility, excreta microbial load, feed choice, performance, carcass and meat traits. Animal. 10: 1923-1930.

DeFoliart, G.-Nakagaki, B.-Sunde, M. (1987): Protein quality of the house cricket

Acheta domestica when fed to broiler chicks. Poultry Science. 66: 1367-1371.

EFSA (2015): Scientific Opinion of a risk profile related to production and consumption of insects as food and feed. EFSA Journal. 13. 10: 4257.

Esmail, S. H. (2017): Are alternative sources of poultry protein efficient? All About Feed. Special Issue. Feed Efficiency. June. 22-25.

Factfish (2018): Broad beans, horse beans, production quantity (tons) - for all countries. http://www.factfish.com/statistic/broad\%20beans\%2C\%20horse $\% 20$ beans\%2C\%20production\%20quantity (Last accessed 3 May 2018)

FAO (2014): The State of World Fisheries and Aquaculture: Opportunities and Challenges. FAO. Rome.

Gonzalez-Perez, S.-Merck, K. B.-Vereijken, J. M.-van Koningsveld, G. A.Gruppen, H.- Voragen, A. G. J. (2002): Isolation and characterization of 
undenatured chlorogenic acid free sunflower (Helianthus annuus) proteins. Journal of Agricultural and Food Chemistry. 50: 1713-1719.

Hasan, M. R.-Chakbari, R. (2009): Use of algae and aquatic macrophytes as feed in small-scale aquaculture: a review. FAO Fisheries and Aquaculture Technical Paper. No. 531. FAO. Rome.

Heincinger, M.-Balogh, K.-Fébel, H.-Erdélyi, M.-Mézes, M. (2011): Effect of diets with different inclusion levels of distillers dried grain with solubles combined with lysine and methionine supplementation on the lipid peroxidation and glutathione status of chickens. Acta Veterinaria Hungarica. 59: 195-204.

Heincinger, M.-Balogh, K.-Mézes, M.-Fébel, H. (2012): Effects of distillers dried grain with soluble (DDGS) on meat quality, lipid peroxide and some of antioxidant status parameters of fattening turkey. Journal of Poultry Science. 49: $268-272$.

Index Mundi (2018): Palm kernel meal production in the world. https://www. indexmundi.com/agriculture/?commodity=palm-kernel-meal\&graph= production (Last accessed 3 May, 2018)

Jones, J. D. (1979): Rapeseed protein concentrate preparation and evaluation. Journal of the American Oil Chemists' Society. 56: 716-721.

Karuga, J. (2017): 10 Countries with largest soybean production. www.worldatlas. com/articles/world-leaders-in-soya-soybean-production-bycountry.html (Last accessed 3 May 2018)

Khan, S.-Naz, S.-Sultan, A.-Aalhidary, I. A.-Abdelrahman, M. M.-Khan, R. U.Khan,

N. A.-Khan, M. A.-Ahmad, S. (2016): Worm meal: a potential source of alternative protein in poultry feed. World's Poultry Science Journal. 72: 93102.

Kovács, M.-Tuboly, T.-Mézes, M.-Balogh, K.-Gerencsér, Zs.-Matics, Zs.-Dal Bosco, A.-Szendrö, Zs.-Tornyos, G.-Hafner, D.-Milisits, G.-BaloghZándoki, E.-Dalle Zotte, A. (2016): Effect of dietary supplementation of Spirulina (Arthrospira platensis) and thyme (Thymus vulgaris) on serum biochemistry, immune response and antioxidant status of rabbits. Annals of Animal Science. 16: 181- 195.

Marquardt, R. R.-Arbid, M. S. S. (1988): Protection against the toxic effects of the favism factor (divicine) in rats by vitamins $\mathrm{E}, \mathrm{A}$ and $\mathrm{C}$ and iron chelating agents. Journal of Science in Food and Agriculture. 43: 155-166.

McLeod, A. (ed.) (2011): World Livestock 2011: Livestock in Food Security. FAO, Rome. http://www.fao.org/docrep/014/i2373e/i2373e.pdf. (Last accessed 4 May, 2018)

Mordor Intelligence (2017): Europe Pea Market - Growth and Trends. Forecast to 2017-2022. www.mordorintelligence.com/industry-reports/europe-peasmarket (Last accessed 4 May, 2018) 
Moughan, P. J.-Rutherfurd, S. M. (2008): Available lysine in foods: a brief historical overview. Journal of AOAC International. 91: 901-906.

Mulder, W. (2010): Proteins in biomass streams. Report 1134. Platform Groene Grondstoffen. Wageningen.

Petterson, D. S. (2000): The use of lupines in feeding systems. Review. AsianAustralasian Journal of Animal Science. 13: 861-882.

Pieper, R.-Taciak, M.-Pieper, L.-Święch, E.-Tuśnio, A.-Barszcz, M.-Vahjen, W.- Skomiat, J.-Zentek, J. (2016): Comparison of the nutritional value of diets containing differentially processed blue sweet lupin seeds or soybean meal for growing pigs. Animal Feed Science and Technology. 221A: 79-86.

Ramos-Elorduy, J.-González, E. A.-Hernández, A. R.-Pino, J. M. (2002): Use of Tenebrio molitor (Coleoptera: Tenebrionidae) to recycle organic wastes and as feed for broiler chickens. Journal of Economic Entomology. 95: 214-220.

Regulation (EC) (2009): No 1069/2009 of the European Parliament and of the Council of 21 October 2009 laying down health rules as regards animal byproducts and derived products not intended for human consumption and repealing Regulation (EC) No 1774/2002. Official Journal of the European Union. L 300/1.

Sen, S.-Makkar, H. P. S.-Becker, K. (1998): Alfalfa saponins and their implication in animal nutrition. Journal of Agricultural and Food Chemistry. 46: $131-140$.

Sujak, A.-Kotlarz, A.-Strobel, W. (2006): Compositional and nutritional evaluation of several lupine seeds. Food Chemistry. 98: 711-719.

Światkiewicz, S.-Arczewska-Włosek, A.-Józefiak, D. (2016): The use of cottonseed meal as a protein source for poultry: an updated review. World's Poultry Science Journal. 72: 473-484.

Tripathi, M. K.-Mishra, A. S. (2007): Glucosinolates in animal nutrition: A review.

Animal Feed Science and Technology. 132: 1-27.

Yaowang, C. (1989): Animal raising and plant cultivation on an integrated fish farm. Integrated Fish Farming in China. Chapter 9. NACA Technical Manual

7. Bangkok.

Vadivel, V.-Janardhanan, K. (2000): Nutritional and anti-nutritional composition of velvet bean: an under-utilized food legume in south India. International Journal of Food Science and Nutrition. 51: 279-287.

Vadivel, V.-Pugalenthi, M.-Doss, A.-Parimelazhagan, T. (2011): Evaluation of velvet bean meal as an alternative protein ingredient for poultry feed. Animal. 5: 67-73. 